\title{
Electrospray ionisation mass spectrometry of ruthenium and palladium complexes with oligonucleotides $^{a}$
}

\author{
Jennifer L. Beck, Amy Humphries, Margaret M. Sheil and Stephen F. Ralph* \\ Department of Chemistry, University of Wollongong, Northfields Avenue, Wollongong, NSW, 2522 Australia. \\ E-mail: stephen_ralph@uow.edu.au
}

\begin{abstract}
Electrospray ionisation mass spectrometry (ESI-MS) was used to characterise complexes formed in reactions between ruthenium or palladium compounds and oligonucleotides containing eight bases. ESI mass spectra of reactions involving cis- or trans$\left[\mathrm{RuCl}_{2}(\mathrm{DMSO})_{4}\right]$ showed in-source fragmentation of the reaction products. In contrast, spectra obtained from reactions involving cis$\left[\mathrm{Ru}(\text { bipy })_{2} \mathrm{Cl}_{2}\right]$, mer-[Ru(terpy)Cl $\left.\mathrm{Cl}_{3}\right]$ or $\left[\mathrm{Pd}(\mathrm{en}) \mathrm{Cl}_{2}\right]$ were consistent with the chelating ligands remaining bound to metaloligonucleotide products. The most abundant complex formed when $c i s$ - $\left[\mathrm{Ru}(\mathrm{bipy})_{2} \mathrm{Cl}_{2}\right]$ reacted with $\mathbf{5}^{\prime}$-GGCTAGCC-3' comprised one $\operatorname{Ru}(\text { bipy })_{2}$ unit bound to the oligonucleotide. Smaller amounts of a complex in which two $R u(b i p y)_{2}$ units were bound were detected in reactions containing excess ruthenium. $\mathrm{Mer}$-[Ru(terpy) $\left.\mathrm{Cl}_{3}\right]$ reacted more slowly with oligonucleotides than cis$\left[\mathrm{Ru}(\text { bipy })_{2} \mathrm{Cl}_{2}\right]$ under otherwise identical conditions. However, the rates of reactions involving $\mathrm{mer}$ - $\left[\mathrm{Ru}\left(\right.\right.$ terpy)Cl $\left.\mathrm{Cl}_{3}\right]$ were increased by addition of the reducing agent ascorbate. $\left[\mathrm{Pd}(\mathrm{en}) \mathrm{Cl}_{2}\right]$ reacted more extensively with $5^{\prime}$-GGCTAGCC-3' than the ruthenium complexes, since ESI mass spectra showed ions arising from complexes containing two, three and four Pd(en) moieties bound to the oligonucleotide. Mass spectra obtained after purifying the reaction mixture by HPLC indicated that the major complex contained only two Pd(en) units bound to the oligonucleotide, suggesting that ions containing three or four Pd(en) units were formed predominantly by gas-phase chemistry in the ion source.
\end{abstract}

Keywords: electrospray ionisation mass spectrometry, ruthenium complexes, palladium complexes, oligonucleotides, oligonucleotide adducts, metal ions

\section{Introduction}

The negatively charged sugar-phosphate backbone and heteroatoms present in the bases of nucleic acids provide a variety of potential binding sites for metal ions. Within cells, magnesium and potassium ions neutralise the negativelycharged phosphate groups. This minimises electrostatic repulsion between phosphate groups thereby stabilising nucleic acid structures. ${ }^{1}$ Potassium ions also play critical roles in stabilising specific nucleic acid structural motifs present in ribozymes and telomeres. ${ }^{1}$ For example, in telomeric DNA potassium forms an octacoordinate complex with the O-6 atoms of eight guanine residues, stabilising a quadruplex structure. ${ }^{2}$ Transition metals such as platinum(II), palladium(II) and ruthenium(II) form covalent

${ }^{a}$ Dedicated to the memory of Professor Allan Maccoll bonds with the nitrogen atoms present in nucleic acid bases. ${ }^{3}$ These include the N3 of cytosine, N1 of adenine and N7 of guanine and adenine. Alternatively, if the metal complex contains planar aromatic ligands intercalation between purine and pyrimidine bases may occur. ${ }^{3}$

Many applications have been proposed for metal complexes that bind selectively to specific regions of nucleic acids. These include uses as spectroscopic probes, metallofootprinting agents, conformational probes, sequence-selective cleavage agents and luminescent stains. ${ }^{1,3}$ The most important application to date, however, has been as chemotherapeutic agents. Cis-diamminedichloroplatinum(II) (cisplatin) is one of the most widely used chemotherapeutic agents, and has proven particularly successful in combination with other drugs for the treatment of testicular and ovarian cancer. ${ }^{4-6}$ A critical event in the mechanism of action of cisplatin is the formation of an adduct in which platinum coordinates to the N7 atoms of two adjacent deoxyguanosines on the same strand of DNA. While this 
1,2-intrastrand $\mathrm{GpG}$ lesion accounts for over half of all platinum bound to DNA, other adducts are formed in significant amounts including 1,2-intrastrand ApG, and 1,3-intrastrand $\mathrm{GpXpG}$ and ApXpG complexes $(\mathrm{X}=\text { any base) })^{7,8}$ Both types of 1,2-intrastrand crosslinks bend and unwind double stranded DNA to produce structures that are recognised by specific classes of DNA binding proteins. ${ }^{9}$ The resulting Pt-DNA-protein assemblies are believed to be critical for the antitumour action of the platinum complex.

Extensive efforts have been directed towards finding analogues of cisplatin with either superior therapeutic activity, or activity against different and more prevalent types of cancer. Systematic variation of the structure of cisplatin allowed identification of a series of structure/activity rules for antitumour activity, adherence to which produced complexes with similar activity to that of cisplatin. ${ }^{10}$ As a consequence, attention is now being focussed on complexes of platinum and other metal ions with little or no structural similarities to cisplatin, with the expectation that they may interact differently with DNA, and therefore exhibit a different spectrum of anticancer activity. This approach has led to the discovery of several new classes of metal complexes, some of which are undergoing clinical trials. These include dinuclear and trinuclear platinum complexes, ${ }^{11}$ platinum complexes with trans orientated leaving groups, ${ }^{12}$ ruthenium sulfoxide complexes ${ }^{13}$ and various classes of organometallic compounds. ${ }^{14}$ In some cases these complexes display activity against cisplatin-resistant tumours, or specifically target metastatic tumour cells.

In order to understand how these different complexes act as antitumour agents it is essential to determine the precise nature of their binding to nucleic acids. Sequence selectivity is usually established by enzymatic methods, while nuclear magnetic resonance (NMR) spectroscopy and, to a lesser extent, X-ray crystallography have been used to provide information on the structural consequences of metals binding to short oligonucleotides. During the last decade the development of electrospray ionisation mass spectrometry (ESI-MS) has allowed accurate mass measurements to be performed on relatively large oligonucleotides including plasmid DNA. ${ }^{15-19}$ ESI-MS has also been used for the characterisation of covalent ${ }^{20-24}$ and non-covalent ${ }^{25-28}$ drug-DNA complexes. For example, ESI-MS studies on DNA bound to the antibiotic hedamycin revealed that the drug selectively binds to specific DNA sequences and significantly increased the stability of duplex DNA in the gas phase. ${ }^{20-22}$ Several other reports have described the use of ESI-MS for characterising complexes formed in reactions between short oligonucleotides and platinum(II) complexes. ${ }^{21,23,24}$

To date there have been very few reports describing the application of ESI-MS for characterising oligonucleotide complexes containing metal ions other than platinum(II). Rombeck and Lippert recently characterised a ternary complex formed between a palladium(II) tripeptide complex and a tetranucleotide using ESI-MS in conjunction with NMR spectroscopy. ${ }^{29}$ We have also used ESI-MS and ${ }^{1} \mathrm{H}$ NMR spectroscopy for examining the reactions of the complexes cis- and trans-[ $\left.\mathrm{RuCl}_{2}(\mathrm{DMSO})_{4}\right]$ with deoxyribonucleotides. ${ }^{30}$ In this report we present the preliminary results of an investigation of the reactions of these complexes, as well as cis-[Ru(bipy) $\left.{ }_{2} \mathrm{Cl}_{2}\right]$, mer-[Ru(terpy) $\left.\mathrm{Cl}_{3}\right]$ and $\left[\mathrm{Pd}(\mathrm{en}) \mathrm{Cl}_{2}\right]$ with oligonucleotides. Our primary objective was to determine whether the products formed in these reactions were sufficiently stable to allow their characterisation by ESI-MS. In addition, we wished to determine whether ESI-MS could reliably provide information on the stoichiometry of metal/oligonucleotide complexes.

\section{Experimental}

The structures of the metal complexes examined in this study are illustrated in Figure 1. Cis-dichlorobis(2,2'bipyridine)ruthenium(II) dihydrate and dichloroethylenediamine-palladium(II) were purchased from Strem (Newburyport, MA, USA) and Aldrich Chemicals (Milwaukee, WI, USA), respectively. Trichloro(terpyridine)ruthenium(III), cis- and trans-[ $\left.\mathrm{RuCl}_{2}(\mathrm{DMSO})_{4}\right]$ were synthesised using literature procedures. ${ }^{31-33}$ Ruthenium(III) chloride hydrate, dimethylsulfoxide and 2,2':6',2"-terpyridine were obtained from Aldrich. All other reagents were obtained from Ajax Chemicals (Sydney, Australia) and were of Analytical Grade. Milli Q water was used to prepare all aqueous solutions.

Oligodeoxyribonucleotides (5'-GGCTAGCC-3', $M_{r}=$ 2410.6 Da and 5'-TACGCGTA-3', $\left.M_{r}=2409.6 \mathrm{Da}\right)$ were obtained from Bresatec (now Geneworks, Adelaide, South Australia) as the "trityl-on" derivatives carrying 5' and 3' hydroxyl termini. The oligonucleotides were deprotected using standard procedures and purified by two stages of reversed phase high performance liquid chromatography (HPLC) as described previously. ${ }^{21}$ The purity of oligonucleotides after HPLC was confirmed by ESI-MS.
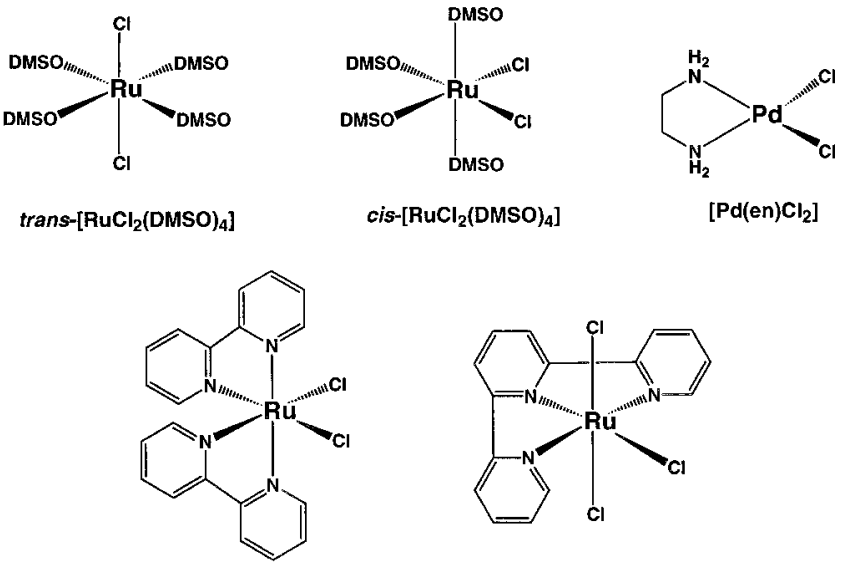

cis-[Ru(bipy) $\left.{ }_{2} \mathrm{Cl}_{2}\right]$

mer-[Ru(terpy) $\left.\mathrm{Cl}_{3}\right]$

Figure 1. Structures of the metal complexes used in this study. 
The concentrations of oligonucleotides were estimated by measurement of ultraviolet (UV) absorbance at $260 \mathrm{~nm}$ using values of $\varepsilon_{260}$ for adenine, guanine, cytosine and thymine of $15400,11700,7300$ and $8300 \mathrm{M}^{-1} \mathrm{~cm}^{-1}$, respectively. ${ }^{34}$

HPLC separations were carried out using a Beckman HPLC system equipped with a model UV166 detector and Gold Nouveau ${ }^{\mathrm{TM}}$ software. An octadecasilyl (C18) column (Deltapak radial cartridge, Waters) was used for HPLC purification. The column was equilibrated with $10 \mathrm{mM}$ aqueous ammonium acetate prior to use. Metal/oligonucleotide reaction mixtures were separated using either a $0-40 \%$ or $0-60 \%$ acetonitrile gradient in $10 \mathrm{mM}$ ammonium acetate. The column flow rate was maintained at $1 \mathrm{~mL} \min ^{-1}$ and the total time for a separation was 30 minutes.

Freshly-prepared aqueous solutions containing metal complexes were used in all experiments and were sonicated for 20 minutes before use to ensure complete dissolution. In a typical experiment, a solution containing the oligonucleotide dissolved in ammonium acetate $(\mathrm{pH}$ 6.8) was heated in a water bath to at least $20^{\circ} \mathrm{C}$ above the melting temperature (calculated by Geneworks) of the self-complementary oligonucleotide. This ensured that the solution contained only single stranded DNA, which persisted after rapid cooling to room temperature. The required volume of solution containing the metal complex of interest was then added to give a metal : (single-stranded) oligonucleotide ratio of $1: 1,2: 1$ or $4: 1$. The final concentration of oligonucleotide was $0.17 \mathrm{mM}$ except in the case of reactions with mer-[Ru(terpy) $\left.\mathrm{Cl}_{3}\right]$, where lower concentrations were necessary to keep the complex in solution and the concentration of oligonucleotide was $\leq 0.025 \mathrm{mM}$. The final concentration of ammonium acetate was $5.1 \mathrm{mM}$. After allowing the reaction to proceed in the dark under ambient conditions (approx. $25^{\circ} \mathrm{C}$ ), aliquots were removed and diluted up to two-fold using acetonitrile just prior to analysis by ESI-MS. In some cases the remainder of the reaction mixture was separated by HPLC into fractions as described above. The fractions were dried by vacuum centrifugation using a Savant SpeedVac ${ }^{\mathrm{TM}}$ and stored at $-20^{\circ} \mathrm{C}$ until required. Fractions were redissolved in $3 \mathrm{mM}$ ammonium acetate (in $50 \%$ acetonitrile) just prior to analysis by ESI-MS. The final concentration of single-stranded oligonucleotide analysed in this way was $15-90 \mathrm{pmol} \mathrm{L}^{-1}$. The lower concentration $\left(15 \mathrm{pmol} \mathrm{L}^{-1}\right)$ was necessary only for reaction mixtures containing mer-[Ru(terpy) $\left.\mathrm{Cl}_{3}\right]$.

ESI-MS spectra were obtained using a VG Biotech (now Micromass, Wyntheshawe, UK) Quattro ${ }^{\mathrm{TM}}$ mass spectrometer equipped with an electrospray ionisation source and tandem mass analyser of quadrupole, hexapole, quadrupole configuration. Each quadrupole has a $\mathrm{m} / \mathrm{z}$ range of 4000 . The resolution of the spectrometer was set to 2.0 Da (peak width at half-height). Therefore reported $\mathrm{m} / \mathrm{z}$ values correspond to molecular weights determined using the average atomic weights of each of the elements present. The electrospray solvent was 50 : 50 acetonitrile : Milli Q water.
For each analysis, $10 \mu \mathrm{L}$ of sample was introduced into the source at a flow rate of $5 \mu \mathrm{L} \mathrm{min}{ }^{-1}$. A flow of warm dry nitrogen $\left(80^{\circ} \mathrm{C}, 1 \mathrm{~atm}\right)$ assisted evaporation of the solvent. The electrospray probe tip potential was $2.5 \mathrm{kV}$, with $0.2 \mathrm{kV}$ on the chicane counter electrode. The photomultiplier was set to $650 \mathrm{~V}$. A cone potential of $25 \mathrm{~V}$ was used in all experiments. Spectra were acquired in negative ion mode over the range $\mathrm{m} / \mathrm{z} 400-1800$ at a scan rate of $100 \mathrm{~m} / \mathrm{z} \mathrm{s}^{-1}$. Ten to fifteen scans were summed to obtain representative spectra. The data were calibrated against a standard CsI solution $(1.5 \mu \mathrm{M})$ over the same $m / z$ range.

\section{Results and discussion}

\section{Reactions involving cis- and trans- $\left[\mathrm{RuCl}_{2}\left(\mathrm{DMSO}_{4}\right]\right.$}

Mixtures containing 5'-GGCTAGCC-3' and 1, 2 and 4 equivalents of either cis- or trans- $\left[\mathrm{RuCl}_{2}(\mathrm{DMSO})_{4}\right]$ were allowed to react under ambient conditions for 24 hours before recording their ESI mass spectra. At this time, the spectra of reaction mixtures prepared using either 1 or 2 equivalents of the metal complexes (not shown) were dominated by the $[\text { oligo }-4 \mathrm{H}]^{4-}$ and $[\text { oligo }-3 \mathrm{H}]^{3-}$ ions of unreacted oligonucleotide. Ions corresponding to reaction products were also present, albeit in significantly lower abundance than in the spectra of the $4: 1$ reaction mixtures. Figure 2 and Table 1 present the spectra and assignments for the $4: 1$ reaction mixtures with both complexes. In the spectrum of the reaction mixture prepared using $c i s-\left[\mathrm{RuCl}_{2}(\mathrm{DMSO})_{4}\right]$ after 24 hours reaction time [Figure 2(a)] the most abundant ion was at $m / z$ 802.2, attributable to [oligo-3H] $]^{3-}$. The next

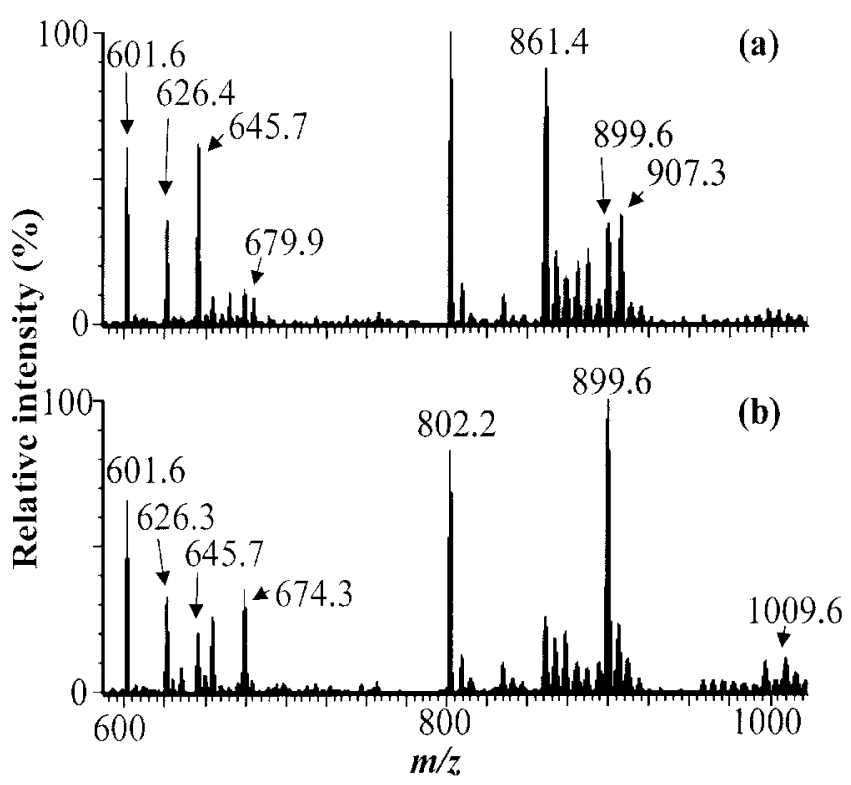

Figure 2. Negative ion ESI mass spectra of solutions prepared by allowing 5'-GGCTAGCC-3' to react for 24 hours with 4 equivalents of either: (a) cis- $\left[\mathrm{RuCl}_{2}(\mathrm{DMSO})_{4}\right]$ or (b) trans[RuCl ${ }_{2}\left(\mathrm{DMSO}_{4}\right]$. 
Table 1. ESI mass spectral data for reaction mixtures containing a 4 : 1 ratio of either cis- or trans-[RuCl ${ }_{2}\left(D_{M}\right.$ SO $\left._{4}\right]$ and 5'-GGCTAGCC-3'.

\begin{tabular}{|c|c|c|c|}
\hline$C i s-\left[\mathrm{RuCl}_{2}(\mathrm{DMSO})_{4}\right]$ & \multicolumn{3}{|c|}{ Trans $-\left[\mathrm{RuCl}_{2}(\mathrm{DMSO})_{4}\right]$} \\
\hline $\begin{array}{l}\quad m / z \\
\text { (rel. intensity) }\end{array}$ & $\begin{array}{c}\text { Assignment } \\
\text { (calculated } \mathrm{m} / \mathrm{z} \text { ) }\end{array}$ & $\begin{array}{l}\quad m / z \\
\text { (rel. intensity) }\end{array}$ & $\begin{array}{c}\text { Assignment } \\
\text { (calculated } \mathrm{m} / \mathrm{z} \text { ) }\end{array}$ \\
\hline $\begin{array}{l}601.6 \\
(61 \%)\end{array}$ & $\begin{array}{l}\text { [oligo }-4 \mathrm{H}]^{4-} \\
\quad(601.7)\end{array}$ & $\begin{array}{l}601.6 \\
(66 \%)\end{array}$ & $\begin{array}{l}{[\text { oligo }-4 \mathrm{H}]^{4-}} \\
\quad(601.7)\end{array}$ \\
\hline $\begin{array}{l}626.4 \\
(36 \%)\end{array}$ & $\begin{array}{c}{[\mathrm{Ru}(\text { oligo })-6 \mathrm{H}]^{4-}} \\
(626.4)\end{array}$ & $\begin{array}{l}626.3 \\
(33 \%)\end{array}$ & $\begin{array}{c}{[\mathrm{Ru}(\text { oligo })-6 \mathrm{H}]^{4-}} \\
(626.4)\end{array}$ \\
\hline $\begin{array}{l}645.7 \\
(62 \%)\end{array}$ & $\begin{array}{c}{[\mathrm{Ru}(\mathrm{DMSO})(\text { oligo })-6 \mathrm{H}]^{4-}} \\
(645.9)\end{array}$ & $\begin{array}{l}645.7 \\
(20 \%)\end{array}$ & $\begin{array}{c}{[\mathrm{Ru}(\mathrm{DMSO})(\text { oligo })-6 \mathrm{H}]^{4-}} \\
(645.9)\end{array}$ \\
\hline $\begin{array}{l}654.9 \\
(9 \%)\end{array}$ & $\begin{array}{c}{[\mathrm{Ru}(\mathrm{DMSO})(\text { oligo }) \mathrm{Cl}-5 \mathrm{H}]^{4-}} \\
(655.0) \mathrm{OR} \\
{\left[\mathrm{Ru}(\mathrm{DMSO})(\text { oligo })\left(\mathrm{H}_{2} \mathrm{O}\right)_{2}-6 \mathrm{H}\right]^{4}} \\
(654.9)\end{array}$ & $\begin{array}{l}654.8 \\
(26 \%)\end{array}$ & $\begin{array}{c}{[\mathrm{Ru}(\mathrm{DMSO})(\text { oligo }) \mathrm{Cl}-5 \mathrm{H}]^{4-}} \\
(655.0) \mathrm{OR} \\
{\left[\mathrm{Ru}(\mathrm{DMSO})(\text { oligo })\left(\mathrm{H}_{2} \mathrm{O}\right)_{2}-6 \mathrm{H}\right]^{4-}} \\
(654.9)\end{array}$ \\
\hline $\begin{array}{l}665.3 \\
(10 \%)\end{array}$ & $\begin{array}{c}{\left[\mathrm{Ru}(\mathrm{DMSO})_{2}(\text { oligo })-6 \mathrm{H}\right]^{4-}} \\
(665.4)\end{array}$ & & \\
\hline $\begin{array}{l}674.4 \\
(12 \%)\end{array}$ & $\begin{array}{c}{\left[\mathrm{Ru}(\mathrm{DMSO})_{2}(\text { oligo }) \mathrm{Cl}-5 \mathrm{H}\right]^{4-}} \\
(674.6) \mathrm{OR} \\
{\left[\mathrm{Ru}(\mathrm{DMSO})_{2}(\text { oligo })\left(\mathrm{H}_{2} \mathrm{O}\right)_{2}-6 \mathrm{H}\right]^{4-}} \\
(674.5)\end{array}$ & $\begin{array}{l}674.3 \\
(35 \%)\end{array}$ & $\begin{array}{c}{\left[\mathrm{Ru}(\mathrm{DMSO})_{2}(\text { oligo }) \mathrm{Cl}-5 \mathrm{H}\right]^{4-}} \\
(674.6) \mathrm{OR} \\
{\left[\mathrm{Ru}(\mathrm{DMSO})_{2}(\text { oligo })\left(\mathrm{H}_{2} \mathrm{O}\right)_{2}^{-}\right.}\end{array}$ \\
\hline $\begin{array}{l}679.9 \\
(9 \%)\end{array}$ & $\begin{array}{c}{\left[\mathrm{Ru}(\mathrm{DMSO})_{2}(\mathrm{oligo})\left(\mathrm{CH}_{3} \mathrm{CN}\right)\left(\mathrm{H}_{2} \mathrm{O}\right)-6 \mathrm{H}\right]^{4-}} \\
(680.2) \mathrm{OR} \\
{\left[\mathrm{Ru}(\mathrm{DMSO})_{2}(\text { oligo })(\mathrm{Cl})\left(\mathrm{H}_{2} \mathrm{O}\right)-5 \mathrm{H}\right]^{4-}} \\
(679.1)\end{array}$ & $\begin{array}{l}679.0 \\
(4 \%)\end{array}$ & $\begin{array}{c}{\left[\mathrm{Ru}(\mathrm{DMSO})_{2}(\text { oligo })\left(\mathrm{CH}_{3} \mathrm{CN}\right)\left(\mathrm{H}_{2} \mathrm{O}\right)-6 \mathrm{H}\right]^{4}} \\
(680.2) \mathrm{OR} \\
{\left[\mathrm{Ru}(\mathrm{DMSO})_{2}(\text { oligo })(\mathrm{Cl})\left(\mathrm{H}_{2} \mathrm{O}\right)-5 \mathrm{H}\right]^{4-}} \\
(679.1)\end{array}$ \\
\hline $\begin{array}{c}802.2 \\
(100 \%)\end{array}$ & $\begin{array}{l}{[\text { oligo }-3 \mathrm{H}]^{3-}} \\
\quad(802.5)\end{array}$ & $\begin{array}{l}802.2 \\
(82 \%) \\
\end{array}$ & $\begin{array}{l}{[\text { oligo }-3 \mathrm{H}]^{3-}} \\
\quad(802.5)\end{array}$ \\
\hline $\begin{array}{l}809.4 \\
(14 \%)\end{array}$ & $\begin{array}{c}{[\text { oligo }+\mathrm{Na}-4 \mathrm{H}]^{3-}} \\
(808.6)\end{array}$ & $\begin{array}{l}809.5 \\
(13 \%)\end{array}$ & $\begin{array}{c}{[\text { oligo }+\mathrm{Na}-4 \mathrm{H}]^{3-}} \\
(808.6)\end{array}$ \\
\hline $\begin{array}{l}835.2 \\
(10 \%)\end{array}$ & $\begin{array}{c}{[\mathrm{Ru}(\text { oligo })-5 \mathrm{H}]^{3-}} \\
(835.6)\end{array}$ & $\begin{array}{l}835.2 \\
(10 \%)\end{array}$ & $\begin{array}{c}{[\mathrm{Ru}(\text { oligo })-5 \mathrm{H}]^{3-}} \\
(835.6)\end{array}$ \\
\hline $\begin{array}{l}861.4 \\
(88 \%)\end{array}$ & $\begin{array}{c}{[\mathrm{Ru}(\mathrm{DMSO})(\text { oligo })-5 \mathrm{H}]^{3-}} \\
(861.6)\end{array}$ & $\begin{array}{l}861.4 \\
(25 \%)\end{array}$ & $\begin{array}{c}{[\mathrm{Ru}(\mathrm{DMSO})(\text { oligo })-5 \mathrm{H}]^{3-}} \\
(861.6)\end{array}$ \\
\hline $\begin{array}{l}867.4 \\
(25 \%)\end{array}$ & $\begin{array}{c}{\left[\mathrm{Ru}(\mathrm{DMSO})(\text { oligo })\left(\mathrm{H}_{2} \mathrm{O}\right)-5 \mathrm{H}\right]^{3-}} \\
(867.6)\end{array}$ & $\begin{array}{l}867.1 \\
(18 \%)\end{array}$ & {$\left[\mathrm{Ru}(\mathrm{DMSO})(\mathrm{oligo})\left(\mathrm{H}_{2} \mathrm{O}\right)-5 \mathrm{H}\right]^{3-}(867.6)$} \\
\hline $\begin{array}{l}873.7 \\
(17 \%)\end{array}$ & $\begin{array}{c}{[\mathrm{Ru}(\mathrm{DMSO})(\text { oligo }) \mathrm{Cl}-4 \mathrm{H}]^{3-}} \\
(873.7) \mathrm{OR} \\
{\left[\mathrm{Ru}(\mathrm{DMSO})(\text { oligo })\left(\mathrm{H}_{2} \mathrm{O}\right)_{2}-5 \mathrm{H}\right]^{3-}} \\
(873.6)\end{array}$ & $\begin{array}{l}873.6 \\
(21 \%)\end{array}$ & $\begin{array}{c}{[\mathrm{Ru}(\mathrm{DMSO})(\text { oligo }) \mathrm{Cl}-4 \mathrm{H}]^{3-}} \\
(873.7) \mathrm{OR} \\
{\left[\mathrm{Ru}(\mathrm{DMSO})(\text { oligo })\left(\mathrm{H}_{2} \mathrm{O}\right)_{2}-5 \mathrm{H}\right]^{3-}} \\
(873.6)\end{array}$ \\
\hline $\begin{array}{l}881.2 \\
(21 \%)\end{array}$ & $\begin{array}{c}{\left[\mathrm{Ru}(\mathrm{DMSO})(\text { oligo })\left(\mathrm{H}_{2} \mathrm{O}\right)(\mathrm{Cl})-4 \mathrm{H}\right]^{3-}} \\
(879.7) \mathrm{OR} \\
{\left[\mathrm{Ru}(\mathrm{DMSO})(\text { oligo })\left(\mathrm{H}_{2} \mathrm{O}\right)_{3}-5 \mathrm{H}\right]^{3-}} \\
(879.6)\end{array}$ & $\begin{array}{l}880.9 \\
(10 \%)\end{array}$ & $\begin{array}{c}{\left[\mathrm{Ru}(\mathrm{DMSO})(\text { oligo })\left(\mathrm{H}_{2} \mathrm{O}\right)(\mathrm{Cl})-4 \mathrm{H}\right]^{3-}} \\
(879.7) \mathrm{OR} \\
{\left[\mathrm{Ru}(\mathrm{DMSO})(\text { oligo })\left(\mathrm{H}_{2} \mathrm{O}\right)_{3}-5 \mathrm{H}\right]^{3-}} \\
(879.6)\end{array}$ \\
\hline $\begin{array}{l}887.3 \\
(25 \%)\end{array}$ & $\begin{array}{c}{\left[\mathrm{Ru}(\mathrm{DMSO})_{2}(\text { oligo })-5 \mathrm{H}\right]^{3-}} \\
(887.6)\end{array}$ & $\begin{array}{l}887.2 \\
(8 \%)\end{array}$ & $\begin{array}{c}{\left[\mathrm{Ru}(\mathrm{DMSO})_{2}(\text { oligo })-5 \mathrm{H}\right]^{3-}} \\
(887.6)\end{array}$ \\
\hline
\end{tabular}


Table 1 (continued). ESI mass spectral data for reaction mixtures containing a $4: 1$ ratio of either cis- or trans-[RuCl ${ }_{2}\left(\mathrm{DMSO}_{4}\right]$ and 5 GGCTAGCC-3 .

\begin{tabular}{|c|c|c|c|}
\hline $\begin{array}{l}899.6 \\
(35 \%)\end{array}$ & $\begin{array}{c}{\left[\mathrm{Ru}(\mathrm{DMSO})_{2}(\text { oligo }) \mathrm{Cl}-4 \mathrm{H}\right]^{3-}} \\
(900.0) \mathrm{OR} \\
{\left[\mathrm{Ru}(\mathrm{DMSO})_{2}(\text { oligo })\left(\mathrm{H}_{2} \mathrm{O}\right)_{2}-5 \mathrm{H}\right]^{3-}} \\
(899.6)\end{array}$ & $\begin{array}{c}899.6 \\
(100 \%)\end{array}$ & $\begin{array}{c}{\left[\mathrm{Ru}(\mathrm{DMSO})_{2}(\text { oligo }) \mathrm{Cl}-4 \mathrm{H}\right]^{3-}} \\
(900.0) \mathrm{OR} \\
{\left[\mathrm{Ru}(\mathrm{DMSO})_{2}(\text { oligo })\left(\mathrm{H}_{2} \mathrm{O}\right)_{2}-5 \mathrm{H}\right]^{3-}} \\
(899.6)\end{array}$ \\
\hline $\begin{array}{l}907.3 \\
(37 \%)\end{array}$ & $\begin{array}{c}{\left[\mathrm{Ru}(\mathrm{DMSO})_{2}(\text { oligo })\left(\mathrm{CH}_{3} \mathrm{CN}\right)\left(\mathrm{H}_{2} \mathrm{O}\right)-5 \mathrm{H}\right]^{3-}} \\
(907.3) \mathrm{OR} \\
{\left[\mathrm{Ru}(\mathrm{DMSO})_{2}(\text { oligo })(\mathrm{Cl})\left(\mathrm{H}_{2} \mathrm{O}\right)-4 \mathrm{H}\right]^{3-}} \\
(905.8)\end{array}$ & $\begin{array}{l}906.4 \\
(23 \%)\end{array}$ & $\begin{array}{c}{\left[\mathrm{Ru}(\mathrm{DMSO})_{2}(\text { oligo })\left(\mathrm{CH}_{3} \mathrm{CN}\right)\left(\mathrm{H}_{2} \mathrm{O}\right)-5 \mathrm{H}\right]^{3-}} \\
(907.3) \mathrm{OR} \\
{\left[\mathrm{Ru}(\mathrm{DMSO})_{2}(\text { oligo })(\mathrm{Cl})\left(\mathrm{H}_{2} \mathrm{O}\right)-4 \mathrm{H}\right]^{3-}} \\
(905.8)\end{array}$ \\
\hline $\begin{array}{c}1361.3 \\
(6 \%)\end{array}$ & $\begin{array}{c}{\left[\mathrm{Ru}(\mathrm{DMSO})_{2}(\mathrm{oligo})\left(\mathrm{CH}_{3} \mathrm{CN}\right)\left(\mathrm{H}_{2} \mathrm{O}\right)-4 \mathrm{H}\right]^{2-}} \\
(1361.4) \mathrm{OR} \\
{\left[\mathrm{Ru}(\mathrm{DMSO})_{2}(\text { oligo })(\mathrm{Cl})\left(\mathrm{H}_{2} \mathrm{O}\right)-3 \mathrm{H}\right]^{2-}} \\
(1359.1)\end{array}$ & $\begin{array}{c}1360.2 \\
(3 \%)\end{array}$ & $\begin{array}{c}{\left[\mathrm{Ru}(\mathrm{DMSO})_{2}(\text { oligo })\left(\mathrm{CH}_{3} \mathrm{CN}\right)\left(\mathrm{H}_{2} \mathrm{O}\right)-4 \mathrm{H}\right]^{2-}} \\
(1361.4) \mathrm{OR} \\
{\left[\mathrm{Ru}(\mathrm{DMSO})_{2}(\text { oligo })(\mathrm{Cl})\left(\mathrm{H}_{2} \mathrm{O}\right)-3 \mathrm{H}\right]^{2-}} \\
(1359.1)\end{array}$ \\
\hline
\end{tabular}

most abundant ions were those attributed to $[\mathrm{Ru}(\mathrm{DMSO})(\text { oligo })-5 \mathrm{H}]^{3-}(\mathrm{m} / \mathrm{z}$ 861.4) and [Ru(DMSO)(oligo) $-6 \mathrm{H}]^{4-}(\mathrm{m} / \mathrm{z} 645.7)$, respectively.

After 24 hours the spectrum of the reaction mixture prepared using a $4: 1$ ratio of trans- $\left[\mathrm{RuCl}_{2}(\mathrm{DMSO})_{4}\right]$ and 5 GGCTAGCC-3 [Figure 2(b)], also contained abundant ions from the unreacted oligonucleotide at $\mathrm{m} / \mathrm{z} \quad 601.6$ [oligo $-4 \mathrm{H}]^{4-}$ and 802.2 [oligo $\left.-3 \mathrm{H}\right]^{3-}$. However, the most abundant ion in this spectrum was at $\mathrm{m} / \mathrm{z}$ 899.6, attributed to either $\left[\mathrm{Ru}(\mathrm{DMSO})_{2}(\text { oligo }) \mathrm{Cl}-4 \mathrm{H}\right]^{3-}$ (calculated $\mathrm{m} / \mathrm{z}$ 900.0) or $\left[\mathrm{Ru}(\mathrm{DMSO})_{2}(\text { oligo })\left(\mathrm{H}_{2} \mathrm{O}\right)_{2}-5 \mathrm{H}\right]^{3-} \quad$ (calculated $\mathrm{m} / \mathrm{z}$ 899.6), with the resolution of the quadrupole mass analyser not sufficient to distinguish between these possibilities. The spectrum also contained an ion of moderate abundance at $\mathrm{m} / \mathrm{z} 674.3$ consistent with the $4-$ ion of either of these complexes. Another possible assignment for these two ions is that they arise from $\left[\mathrm{Ru}(\mathrm{DMSO})_{2}(\right.$ oligo $\left.)\left(\mathrm{CH}_{3} \mathrm{CN}\right)\right]$, which would be expected to give 3- and 4- ions at $\mathrm{m} / \mathrm{z}, 901.3$ and 675.7 , respectively. This assignment seems less likely since the differences between the calculated and measured $\mathrm{m} / \mathrm{z}$ is 1.7 and 1.4 , respectively.

The hydrolytic chemistry of cis- and trans$\left[\mathrm{RuCl}_{2}(\mathrm{DMSO})_{4}\right]$ has been examined thoroughly in other studies, ${ }^{35}$ and is illustrated schematically in Figure 3. Immediately after dissolution in water, trans-[ $\left.\mathrm{RuCl}_{2}(\mathrm{DMSO})_{4}\right]$ substitutes two mutually cis DMSO ligands for water to generate trans, cis, cis- $\left[\mathrm{RuCl}_{2}(\mathrm{DMSO})_{2}\left(\mathrm{H}_{2} \mathrm{O}\right)_{2}\right](\mathbf{1})$, which subsequently exchanges one chloride ligand for water in a much slower process to give cis, fac-[ $\left.\mathrm{RuCl}(\mathrm{DMSO})_{2}\left(\mathrm{H}_{2} \mathrm{O}\right)_{3}\right]^{+}$(2). Cis- $\left[\mathrm{RuCl}_{2}(\mathrm{DMSO})_{4}\right]$ dissolves in water and immediately loses one DMSO ligand to give cis,fac$\left[\mathrm{RuCl}_{2}(\mathrm{DMSO})_{3}\left(\mathrm{H}_{2} \mathrm{O}\right)\right](3)$, which also subsequently substitutes one of its chloride ligands for water in a much slower process to give $f a c$, cis- $\left[\mathrm{RuCl}(\mathrm{DMSO})_{3}\left(\mathrm{H}_{2} \mathrm{O}\right)_{2}\right]^{+}(4)$. Immediately after dissolution in water therefore, trans$\left[\mathrm{RuCl}_{2}(\mathrm{DMSO})_{4}\right]$ forms complex (1) containing two DMSO
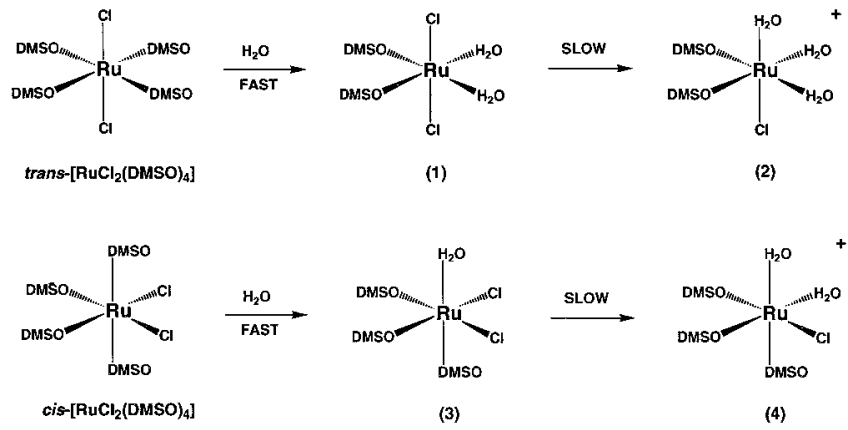

Figure 3. Aqueous solution chemistry of cis- and trans$\left[\mathrm{RuCl}_{2}(\mathrm{DMSO})_{4}\right]$.

ligands and two reactive $\mathrm{Ru}-\mathrm{H}_{2} \mathrm{O}$ bonds, while cis$\left[\mathrm{RuCl}_{2}(\mathrm{DMSO})_{4}\right]$ forms (3), containing three DMSO ligands and only one reactive $\mathrm{Ru}-\mathrm{H}_{2} \mathrm{O}$ bond.

The most abundant ion after reaction of cis$\left[\mathrm{RuCl}_{2}(\mathrm{DMSO})_{4}\right]$ with 5 -GGCTAGCC-3, [Ru(DMSO)(oligo) $-5 \mathrm{H}]^{3-}$, contains either a 2 - or 3-coordinate ruthenium, depending on whether the oligonucleotide is bound to the metal through one or two bases (more below). Based on the hydrolytic chemistry of cis-[ $\left.\mathrm{RuCl}_{2}(\mathrm{DMSO})_{4}\right]$ outlined above, the initial product of this reaction was expected to contain three DMSO ligands. Owing to this and the fact that 2- or 3-coordinate ruthenium complexes have not been reported in solution, it would appear that significant insource fragmentation of the complex had occurred. Consistent with this is the observation of several quadruple and triple charged ions of weak to medium intensity in the $\mathrm{m} / \mathrm{z}$ ranges 626-680 and 835-908, respectively. Amongst these was an ion at $m / z$ 907.3, tentatively assigned to $\left[\mathrm{Ru}(\mathrm{DMSO})_{2}(\text { oligo })\left(\mathrm{H}_{2} \mathrm{O}\right)\left(\mathrm{CH}_{3} \mathrm{CN}\right)-5 \mathrm{H}\right]^{3-}$ (calculated $\mathrm{m} / \mathrm{z}$ 907.3). The 2- and 4- ions of this species were observed at 
$\mathrm{m} / \mathrm{z} 1361.3$ (not shown) and 679.9, respectively. It should be noted that the ion $\left[\mathrm{Ru}(\mathrm{DMSO})_{2}(\text { oligo })\left(\mathrm{H}_{2} \mathrm{O}\right)(\mathrm{Cl})-4 \mathrm{H}\right]^{3-}$ has a calculated $\mathrm{m} / \mathrm{z}$ of 905.8 , with the 2- and 4- ions calculated to be 1359.1 and 679.1, respectively. Modelled isotopic distributions were unable to distinguish between these two sets of possible assignments at the resolution available, and high resolution measurements are required to provide a definitive assignment. Both ions contain either 5- or 6-coordinate ruthenium, depending on whether the oligonucleotide is functioning as a unidentate or bidentate ligand. Substitution and displacement of one or more ligands from this ion gives rise to the ions between $\mathrm{m} / \mathrm{z} 835.2[\mathrm{Ru}(\text { oligo })-5 \mathrm{H}]^{3-}$ and $907.3\left[\mathrm{Ru}(\mathrm{DMSO})_{2}(\text { oligo })\left(\mathrm{CH}_{3} \mathrm{CN}\right)\left(\mathrm{H}_{2} \mathrm{O}\right)-5 \mathrm{H}\right]^{3-}$, and $\mathrm{m} / z$ $626.4[\mathrm{Ru}(\text { oligo })-6 \mathrm{H}]^{4-}$ and $679.9 \quad\left[\mathrm{Ru}(\mathrm{DMSO})_{2}-\right.$ (oligo) $\left.\left(\mathrm{CH}_{3} \mathrm{CN}\right)\left(\mathrm{H}_{2} \mathrm{O}\right)-6 \mathrm{H}\right]^{4-}$. For some of these ions several assignments are possible. This is due to the similarity between calculated values of $\mathrm{m} / \mathrm{z}$ for species whose coordination spheres are identical, except for the presence of either one chloride ligand, one acetonitrile ligand, or two water ligands.

There are also a number of ions evident in the spectrum of the trans isomer reaction mixture [Figure 2(b)] resulting from in-source fragmentation of the product and/or substitution of the ligands. However, the overall relative intensity of these ions is much lower than in the spectrum of the cis isomer. Compare, for example, the relative intensities of the $[\mathrm{Ru}(\mathrm{DMSO})(\text { oligo })-5 \mathrm{H}]^{3-}$ ion $(\mathrm{m} / \mathrm{z}, 861.4 ; 88 \%$ for $\mathrm{cis}, 25 \%$ for trans). The lower abundance of fragment ions suggests that the complexes formed by the trans isomer are more stable than the corresponding complexes of the cis isomer. This is strongly supported by the fact that the most intense ion in the spectrum of the reaction mixture containing the trans isomer $(\mathrm{m} / \mathrm{z}$ 899.6) contained two DMSO ligands, as expected from its hydrolysis chemistry.

These results stand in contrast to our previous studies using a combination of ${ }^{1} \mathrm{H}$ NMR spectroscopy and ESI-MS, which showed that despite their different hydrolytic chemistry, cis- and trans-[ $\left.\mathrm{RuCl}_{2}(\mathrm{DMSO})_{4}\right]$ form an identical mixture of products in reactions with $2^{\prime}$-deoxyguanosine.$^{30}$ For example, the most abundant ion present in the ESI mass spectra of solutions prepared by reacting either cis- or trans$\left[\mathrm{RuCl}_{2}(\mathrm{DMSO})_{4}\right]$ with 5 equivalents of $2^{\prime}$-deoxyguanosine was attributable to cis,cis- $\left[\mathrm{Ru}(\mathrm{DMSO})_{2}\left(2^{\prime}\right.\right.$-deoxyguanosine $\left.)_{2} \mathrm{Cl}\left(\mathrm{H}_{2} \mathrm{O}\right)\right]^{+}$. This ion contains six unidentate ligands coordinated to ruthenium, indicating that minimal fragmentation had occurred during the ionisation process.

The extent of in-source fragmentation of oligonucleotide complexes, particularly those formed by reaction with $c i s-\left[\mathrm{RuCl}_{2}(\mathrm{DMSO})_{4}\right]$, was surprising in view of the abundance of ions attributable to 6-coordinate complexes in reactions of both isomers with $2^{\prime}$-deoxyguanosine. ${ }^{30}$ Significant in-source fragmentation of the expected products was also evident in spectra obtained after reacting both complexes with the hexanucleotide 5'-AGGCCT-3' (Moerman, Ralph and Sheil, unpublished data). This perhaps indicates that the presence of the bulky oligonucleotide may enhance
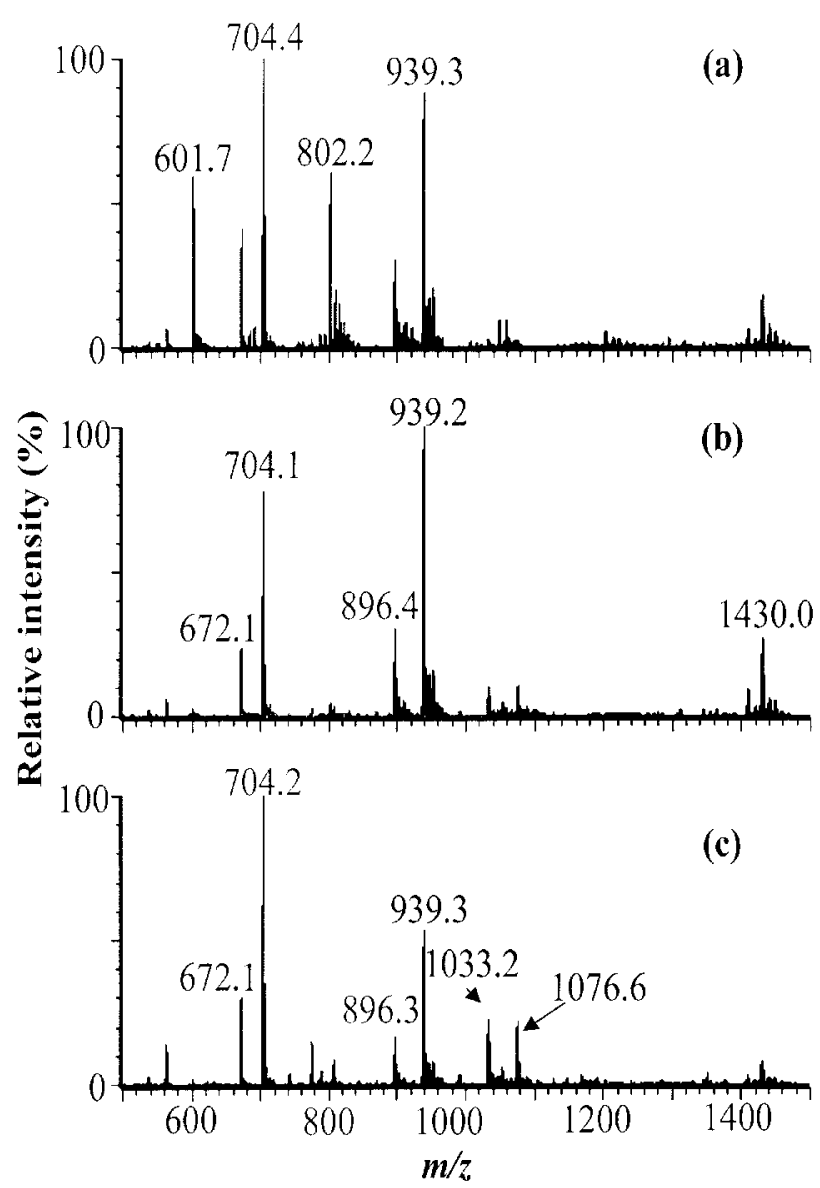

Figure 4. Negative ion ESI mass spectra of solutions prepared by allowing 5'-GGCTAGCC-3' to react with different amounts of cis-[Ru(bipy) $\left.{ }_{2} \mathrm{Cl}_{2}\right]$ for 24 hours. (a) 1 equivalent of cis[Ru(bipy) $\left.{ }_{2} \mathrm{Cl}_{2}\right]$, (b) 2 equivalents of cis-[Ru(bipy) $\left.{ }_{2} \mathrm{Cl}_{2}\right]$, (c) 4 equivalents of cis-[Ru(bipy) $\left.{ }_{2} \mathrm{Cl}_{2}\right]$.

in-source fragmentation because of unfavourable steric interactions.

For both the cis and trans complexes the results indicate that the oligonucleotide has coordinated to the metal. Further experiments are required to determine whether ruthenium is bound to one or more nucleobases, and which nucleobase(s) are involved. A considerable body of evidence is available which suggests that the ruthenium would be bound to one or two of the guanines. ${ }^{30,36,37}$ Since there are four purine nucleobases in 5'-GGCTAGCC-3' it was expected that complexes in which two ruthenium ions are bound to the oligonucleotide may be formed. There was no evidence, however, in the spectra of any reaction mixture (even those with excess metal ion and a 24 hour reaction time) for ions attributable to such complexes. After reaction for a further two days, each of the six reaction mixtures was again analysed by ESI-MS. While the spectra of both $1: 1$ and $2: 1$ reaction mixtures were consistent with greater complexation having occurred, there was still no evidence for ions containing two bound metal ions (data not shown). The spectra of both $4: 1$ reaction mixtures now showed much poorer sig- 
nal-to-noise ratios compared to the mixture after 24 hours, and contained a number of fragment/displacement ions with weak to medium abundance. Overall it appeared that there had been significant decomposition of both solutions, with little evidence for the formation of metal oligonucleotide complexes containing two bound ruthenium ions.

\section{Reactions involving cis-[Ru(bipy) $\left.{ }_{2} \mathrm{Cl}_{2}\right]$}

Figure 4 shows the negative ion ESI mass spectra of $5^{\prime}$ GGCTAGCC-3' reacted with 1, 2 and 4 equivalents of cis$\left[\mathrm{Ru}\right.$ (bipy) $\left.\mathrm{Cl}_{2}\right]$ for 24 hours. The spectrum of the $1: 1$ reaction mixture [Figure 4(a)] contained ions of moderate intensity at $\mathrm{m} / \mathrm{z}, 601.7$ and 802.2 attributable to [oligo $-4 \mathrm{H}]^{4-}$ and $[\text { oligo }-3 \mathrm{H}]^{3-}$, respectively. The most abundant ions in the spectrum were at $\mathrm{m} / \mathrm{z} 704.4$ and 939.3, and are assigned to $\left[\mathrm{Ru}(\text { bipy })_{2}(\text { oligo })-6 \mathrm{H}\right]^{4-}$ and $\left[\mathrm{Ru}(\text { bipy })_{2}(\text { oligo })-5 \mathrm{H}\right]^{3-}$, respectively. There was also an ion at $\mathrm{m} / \mathrm{z}, 563.4$, of much lower intensity arising from the same complex, i.e. $\left[\mathrm{Ru}(\text { bipy })_{2}(\text { oligo })-7 \mathrm{H}\right]^{5-}$. The abundance of the former two ions, and absence of significant ions arising through fragmentation, indicates that these complexes containing chelating bipyridine ligands are considerable more stable than those produced in experiments involving either cis- or trans$\left[\mathrm{RuCl}_{2}(\mathrm{DMSO})_{4}\right]$. The spectra of the $2: 1$ and $4: 1$ reaction mixtures [Figures 4(b) and 4(c), respectively] showed that ions attributed to unreacted oligonucleotide were not present or had dramatically lower intensities than in the spectrum of the $1: 1$ reaction mixture. Ions at $m / z 704.4$ and 939.3 were again the most abundant in the spectra of both reaction mixtures. Also present in these spectra were ions of low intensity at $m / z 1076.6$ attributable to $\left[\left\{\mathrm{Ru}(\text { bipy })_{2}\right\}_{2}(\text { oligo })-7 \mathrm{H}\right]^{3-}$, i.e. containing two metal complexes bound to the oligonucleotide.

Cis-[Ru(bipy) $\left.\mathrm{Cl}_{2}\right]$ contains two stable, chelating, bipyridine ligands and two comparatively labile chloride ligands. In aqueous solution it would be expected that one and possibly both ruthenium-chloride bonds would undergo hydrolysis to give complexes containing labile ruthenium-aqua bonds. The cis stereochemistry of reactive species such as cis-[Ru(bipy) $\left.)_{2} \mathrm{Cl}\left(\mathrm{H}_{2} \mathrm{O}\right)\right]^{+}$and cis$\left[\mathrm{Ru}(\text { bipy })_{2}\left(\mathrm{H}_{2} \mathrm{O}\right)_{2}\right]^{2+}$ suggests that these complexes might react with DNA in a similar fashion to cisplatin, i.e. at sites containing adjacent $\mathrm{GG}$ and $\mathrm{AG}$ sequences. The oligonucleotide examined in this study, 5'-GGCTAGCC-3', contains both a GG and a AG site. Although it is not possible without additional evidence to decide conclusively which bases are coordinated to the metal in the complexes formed here, it would seem likely that the purines in these sequences are involved. On the basis of our data it is also not possible to determine whether the major product of the reaction between $5^{\prime}$-GGCTAGCC-3' and cis-[Ru(bipy) $\left.{ }_{2} \mathrm{Cl}_{2}\right]$ contains fivecoordinate $(2 \times$ bidentate bipyridine ligands and 1 nucleobase of the oligonucleotide), or six-coordinate $(2 \times$ bidentate bipyridine ligands and 2 nucleobases of the oligonucleotide) ruthenium. However, in each spectrum an ion at $m / z \sim 1430$ is present which may arise from six-coor- dinate ruthenium in $\left[\mathrm{Ru}(\text { bipy })_{2}(\text { oligo }) \mathrm{Cl}-3 \mathrm{H}\right]^{2-}(\mathrm{m} / \mathrm{z}$ 1428.3). Studies by other workers using nucleobases (rather than oligonucleotides) reported that reaction of cis$\left[\mathrm{Ru}\right.$ (bipy) $\left.\mathrm{Cl}_{2}\right]$ with excess 9-methylhypoxanthine gave products in which only one chloride ligand had been replaced by a nucleobase. ${ }^{38}$ The lack of complexes in which both chlorides had been substituted was attributed to steric congestion. Electrophoresis studies carried out by Novakova and coworkers were also consistent with the formation of monoadducts in reactions between cis-[Ru(bipy) $\left.{ }_{2} \mathrm{Cl}_{2}\right]$ and pSP73 plasmid DNA. ${ }^{39}$

The spectra of reaction mixtures containing cis$\left[\mathrm{Ru}\right.$ (bipy) $\left.\mathrm{Cl}_{2}\right]$ and either 1,2 or 4 equivalents of $5^{\prime}$ GGCTAGCC-3' also showed ions of weak to moderate intensity at $m / z 672.1$ and 896.4 , corresponding to the 4- and 3 - ions of a species with $M_{r}=2694 \mathrm{Da}$. A number of possible assignments for this species were considered. These include: [Ru(bipy)CN(oligo)] $\left(M_{r}=2694.6 \mathrm{Da}\right.$, calculated $\mathrm{m} / \mathrm{z} 672.7$ and 897.2), [Ru(bipy) ${ }_{2}$ (oligo) - thymine] $\left(M_{r}=2700.1 \mathrm{Da}\right.$, calculated $m / z, 674.0$ and 899.0) and [Ru(bipy)(oligo) $\left.\left(\mathrm{H}_{2} \mathrm{O}\right)_{2}\right]$ $\left(M_{r}=2703.9 \mathrm{Da}\right.$, calculated $\mathrm{m} / z 674.5$ and 899.6). It was thought that the first complex might arise through gas-phase dissociation of acetonitrile to give cyanide, a good ligand for ruthenium. However, the ions at $\mathrm{m} / \mathrm{z}, 672.1$ and $\mathrm{m} / \mathrm{z}, 896.4$ persisted when methanol/water or isopropanol/water were used to flush out lines and were substituted for acetonitrile : water as solvent. Loss of thymine from the coordinated oligonucleotide was also discounted as a possible explanation when the same two ions were observed in mass spectra of reaction mixtures containing cis$\left[\mathrm{Ru}\right.$ (bipy) $\left.\mathrm{Cl}_{2}\right]$ and 5'-CGGCGCCG-3' (data not shown). Loss of cytosine from this oligonucleotide would give 4- and 3 - ions of $\left[\mathrm{Ru}(\text { bipy })_{2}(\right.$ oligo $)$ - cytosine] with $\mathrm{m} / \mathrm{z}, 677.0$ and 903.0, respectively. The final complex [Ru(bipy)(oligo)$\left.\left(\mathrm{H}_{2} \mathrm{O}\right)_{2}\right]$ was not discounted by these additional experiments. However, it would be surprising if there was such a large difference between calculated and measured values of $\mathrm{m} / \mathrm{z}$ for these ions, when the calculated and measured $\mathrm{m} / \mathrm{z}$ of the major species correspond to within $1 \mathrm{~m} / \mathrm{z}$. Further work to characterise these ions, including analysis by tandem mass spectrometer, is planned to determine their identity.

HPLC separation of a reaction mixture prepared by reacting equimolar amounts of cis-[Ru(bipy) $\left.)_{2} \mathrm{Cl}_{2}\right]$ and $5^{\prime}-$ GGCTAGCC-3' produced a chromatogram which showed two peaks. The first peak was sharp, eluted after 11 minutes and was shown by ESI-MS to consist of unreacted oligonucleotide. The second, broader peak eluted between 13 and 20 minutes and consisted of several overlapping peaks. Changing the elution conditions failed to improve significantly the resolution of these peaks. Therefore several fractions were collected between 13 and 20 minutes, the solutions freeze dried, and subsequently redissolved and analysed by ESI-MS. The most abundant ion in each of these mass spectra was that at $\mathrm{m} / \mathrm{z} \quad 704.4$ attributable to $[\mathrm{Ru} \text { (bipy) })_{2}$ (oligo) $\left.-6 \mathrm{H}\right]^{4-}$. Also present in each spectrum was an ion at $\mathrm{m} / z 939.3$ with significantly lower abundance, 


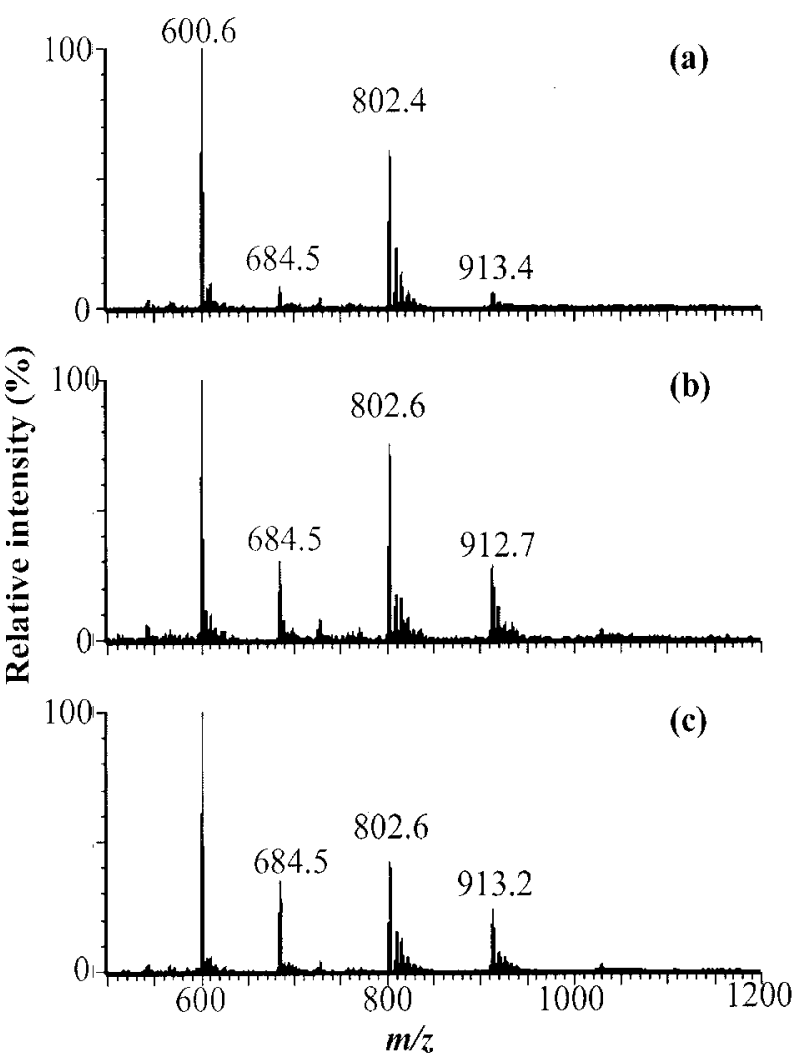

Figure 5. Negative ion ESI mass spectra of solutions prepared by allowing 5'-TACGCGTA-3' to react with different amounts of mer-[Ru(terpy) $\left.\mathrm{Cl}_{3}\right]$ for 24 hours. (a) 1 equivalent of mer[Ru(terpy)Cl $\left.\mathrm{Cl}_{3}\right]$, (b) 2 equivalents of mer-[Ru(terpy) $\left.\mathrm{Cl}_{3}\right]$, (c) 4 equivalents of mer-[Ru(terpy) $\left.\mathrm{Cl}_{3}\right]$.

attributable to $\left[\mathrm{Ru}(\text { bipy })_{2}(\text { oligo })-5 \mathrm{H}\right]^{3-}$. An ion at $m / z 672.1$ was also present in the spectra of all the isolated fractions, with its intensity greatest in the earlier fractions. Several other, as yet unidentified, ions of low abundance were also present in the last two fractions collected.

When the 2:1 and 4:1 reaction mixtures were separated by HPLC, the peak at 11 minutes arising from unreacted 5'-GGCTAGCC-3' was no longer evident, consistent with the very low intensities of ions attributable to unreacted oligonucleotide in mass spectra. A large number of fractions were again obtained from the remaining composite peak in the two chromatograms, and examined by ESI-MS after freeze-drying and redissolution. The profile of ions present in the spectra of fractions collected from the $2: 1$ and $4: 1$ reaction mixtures were very similar to that of the $1: 1$ reaction mixture, with two exceptions. Surprisingly the spectra of several of the earlier fractions collected from the $4: 1$ reaction mixture contained intense ions at $m / z 601.5$ attributable to free oligonucleotide. This was an unexpected result in view of the lack of a peak attributable to free oligonucleotide in the HPLC chromatogram, the lack of a significant ion at this $\mathrm{m} / \mathrm{z}$ in the mass spectrum of the reaction mixture, and the large excess of metal ion present. While this observation may reflect the fact that the products of the reaction are in equilibrium, it is perhaps more likely that decomposition of the complexes occurred subsequent to HPLC purification.

\section{Reactions involving mer-[Ru(terpy) $\left.\mathrm{Cl}_{3}\right]$}

Figure 5 shows the negative ion ESI mass spectra of solutions prepared by reacting 1, 2 and 4 equivalents of mer[Ru(terpy) $\left.\mathrm{Cl}_{3}\right]$ with 5'-TACGCGTA-3' for 24 hours. The most abundant ions in each spectrum were those at $\mathrm{m} / z, 600.6$ and 802.6 attributable to unreacted oligonucleotide. Combined with the low abundance of ions at $\mathrm{m} / \mathrm{z}, 684.5$ and 913.2 attributable to $[\mathrm{Ru}(\text { terpy })(\text { oligo })-7 \mathrm{H}]^{4-}$ and $[\mathrm{Ru}($ terpy)(oligo) $-6 \mathrm{H}]^{3-}$, respectively, this indicates that little reaction had occurred. A similar lack of reactivity was also seen when the study was repeated using 5'-GGCTAGCC-3', indicating that both oligonucleotides display a similar level of reactivity towards the ruthenium(III) complex. Furthermore, comparison of data shown in Figures 4 and 5 suggests that the ruthenium(III) complex is significantly less reactive towards oligonucleotides than cis-[Ru(bipy) $\left.{ }_{2} \mathrm{Cl}_{2}\right]$, containing ruthenium(II). This conclusion is based partially on the lower intensity of ions arising from unreacted oligonucleotide in spectra of reaction mixtures containing the latter complex. After allowing the $4: 1 \quad \operatorname{mer}$ - $\left[\mathrm{Ru}(\right.$ terpy $\left.) \mathrm{Cl}_{3}\right] / 5^{\prime}$ TACGCGTA-3' mixture to react for 10 days, the negative ion ESI mass spectrum (not shown) contained very low intensity ions arising from unreacted oligonucleotide. The ion at $\mathrm{m} / \mathrm{z}, 684.5$ was now the major ion in the spectrum, indicating that the complex corresponding to this ion was very stable.

A wide range of complexes containing ruthenium(III) have been demonstrated to exhibit interesting antitumour and antimetastatic properties. ${ }^{39-43} \mathrm{We}$ decided to investigate the reactions of mer-[Ru(terpy) $\left.\mathrm{Cl}_{3}\right]$, as a representative ruthenium(III) complex, because the stability conferred on the metal complex by the tridentate terpyridine ligand should minimise in-source fragmentation. Furthermore, interactions of this complex with calf thymus DNA and with nucleobases have been examined previously. ${ }^{39,42}$ The oligonucleotides selected for this study were chosen because they offer two different types of binding sites to the metal. The first, 5'-GGCTAGCC-3', contains two separate metal binding regions each consisting of adjacent purines, and is suited for forming 1,2-intrastrand crosslinks with ruthenium. In contrast, 5'-TACGCGTA-3' offers the possibility of forming a crosslink with two purines separated by a pyrimidine (1,3-intrastrand crosslinked product).

A feature of the chemistry of ruthenium(III) complexes is their extremely slow rates of substitution reactions. Consequently, it has been often suggested that the mechanisms of antitumour action of ruthenium(III) complexes must involve reduction to the more reactive + (II) oxidation state, to enable reaction with DNA and other biomolecules. ${ }^{44-47}$ There is no doubt that the ions seen at $m / z 684.5$ and 913.2 in the spectrum of the mer-[Ru(terpy) $\left.\mathrm{Cl}_{3}\right] / 5^{\prime}$-GGCTAGCC-3' reaction mixture arise from a complex containing the 


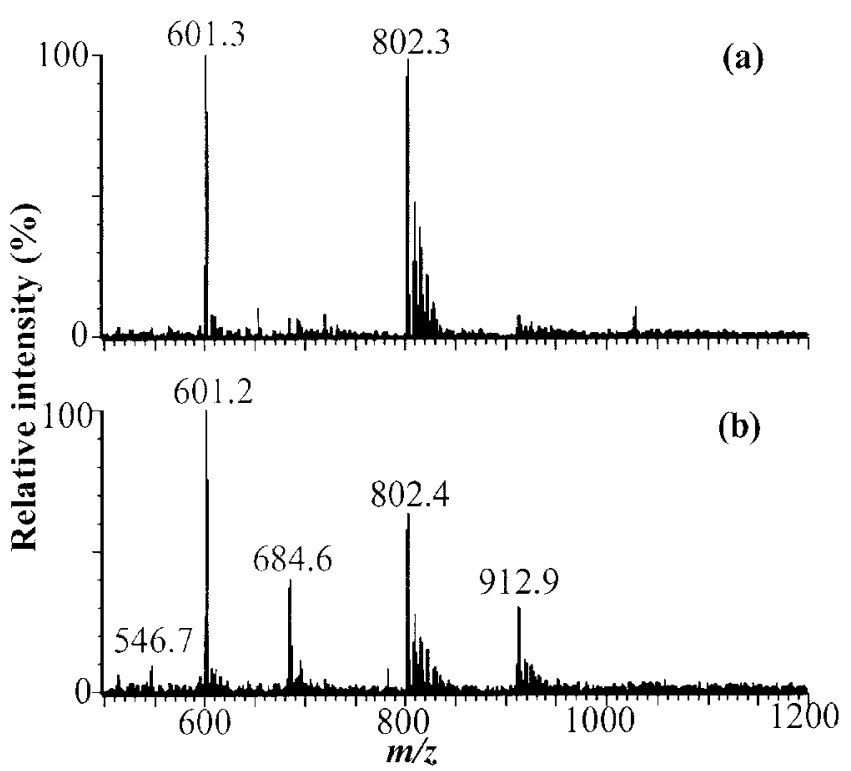

Figure 6. Negative ion ESI mass spectra of solutions prepared by reacting equimolar amounts of mer-[Ru(terpy) $\left.\mathrm{Cl}_{3}\right]$ and 5 GGCTAGCC-3' for 16 hours. (a) no ascorbate added, (b) ascorbate (equimolar with mer-[Ru(terpy) $\left.\mathrm{Cl}_{3}\right]$ ) added.

oligonucleotide bound to ruthenium. However, the spectral resolution was not sufficient to determine whether these ions are attributable to $[\mathrm{Ru}(\text { terpy })(\text { oligo })-7 \mathrm{H}]^{4-}$ and $\left[\mathrm{Ru}(\text { terpy)(oligo) }-6 \mathrm{H}]^{3-}\right.$, containing ruthenium(III), or to $[\mathrm{Ru}(\text { terpy })(\text { oligo })-6 \mathrm{H}]^{4-}$ and $[\mathrm{Ru}(\text { terpy })(\text { oligo })-5 \mathrm{H}]^{3-}$, containing ruthenium(II). Despite this we were able to demonstrate the influence of reducing agents on the rate of formation of ruthenium oligonucleotide products. Figure 6(a) illustrates the ESI mass spectrum of a reaction mixture containing equimolar amounts of mer-[Ru(terpy) $\left.\mathrm{Cl}_{3}\right]$ and $5^{\prime}$ GGCTAGCC-3' after 16 hours. The spectrum contains relatively intense ions from the unreacted oligonucleotide, and very low intensity ions at $\mathrm{m} / \mathrm{z}, 684.3$ and 912.9 attributable to a ruthenium oligonucleotide complex, consistent with little reaction having occurred. Figure $6(\mathrm{~b})$ shows the spectrum of a reaction mixture containing equimolar amounts of mer[Ru(terpy) $\left.\mathrm{Cl}_{3}\right], 5^{\prime}$-GGCTAGCC-3' and ascorbate, after 16 hours reaction time. The intensities of ions at $\mathrm{m} / \mathrm{z} 684.6$ and 912.9 are much greater than in Figure 6(a), indicating that a greater degree of coordination of the oligonucleotide to the metal had taken place. This is presumably the result of reduction of the ruthenium(III) starting material by ascorbate to give the more reactive corresponding ruthenium(II) complex.

A final question that remains to be answered is whether the $\mathrm{Ru}$ (terpy) group is coordinated to one or more nucleobases in the reaction products. In reactions between mer-[Ru(terpy) $\left.\mathrm{Cl}_{3}\right]$ and the bases 9-methylhypoxanthine and 9-ethylguanine, symmetric ruthenium(II) complexes with the formula trans- $\left[\mathrm{Ru}(\text { terpy })(\text { base })_{2}\left(\mathrm{H}_{2} \mathrm{O}\right)\right]^{2+}$ were formed. ${ }^{42}$ This indicated that the complex was capable,

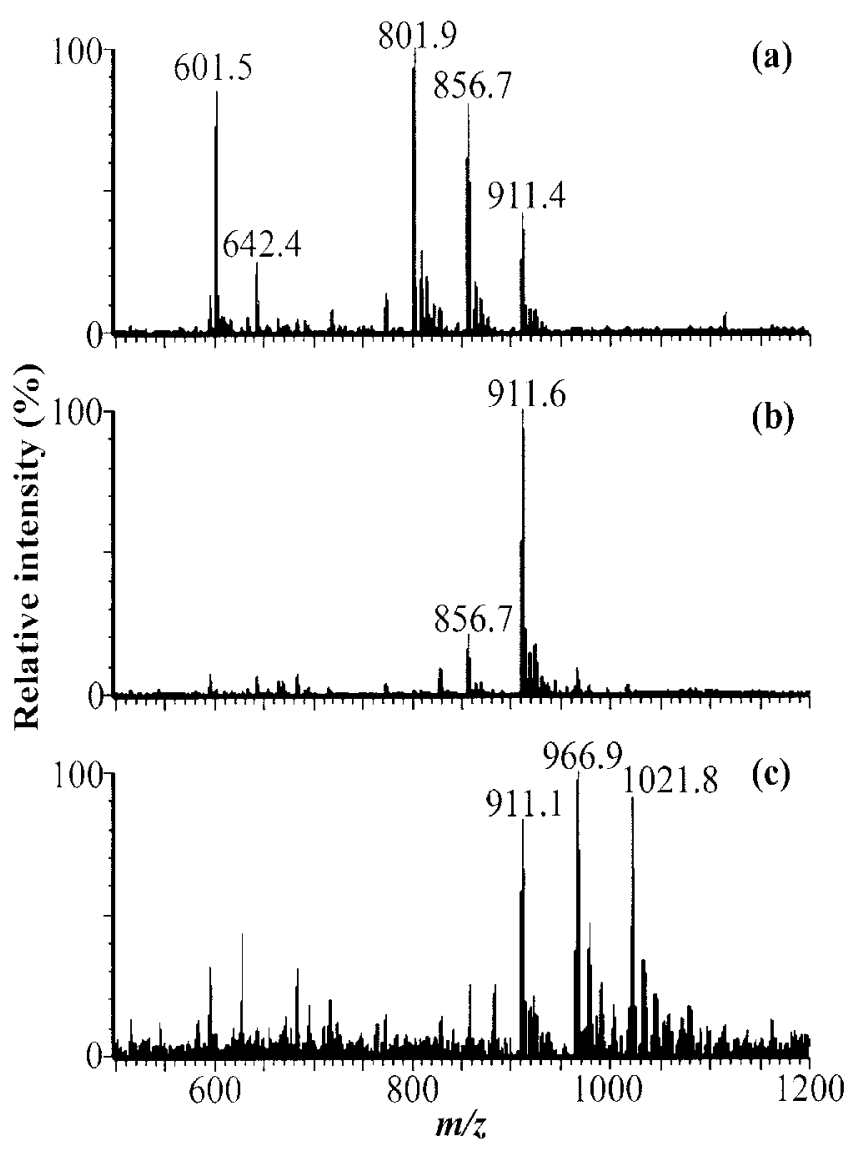

Figure 7. Negative ion ESI mass spectra of solutions prepared by allowing 5'-GGCTAGCC-3' to react with different amounts of $\left[\mathrm{Pd}(\mathrm{en}) \mathrm{Cl}_{2}\right]$ for 24 hours. (a) 1 equivalent of $\left[\mathrm{Pd}(\mathrm{en}) \mathrm{Cl}_{2}\right]$, (b) 2 equivalents of $\left[\mathrm{Pd}(\mathrm{en}) \mathrm{Cl}_{2}\right]$, (c) 4 equivalents of $\left[\mathrm{Pd}(\mathrm{en}) \mathrm{Cl}_{2}\right]$.

unlike cis-[Ru(bipy) $\left.{ }_{2} \mathrm{Cl}_{2}\right]$, of binding to more than one nucleobase, and that reduction of the metal was a facile process. Mer- $\left[\mathrm{Ru}(\right.$ terpy $\left.) \mathrm{Cl}_{3}\right]$ has also been reported to have a significant capacity for forming interstrand crosslinks with calf thymus DNA, again in contrast to $c i s$ - $\left[\mathrm{Ru}(\text { bipy })_{2} \mathrm{Cl}_{2}\right]^{39,42}$ In future work we will address the question of which base(s) in the oligonucleotide the ruthenium is coordinated to by tandem mass spectrometry. Furthermore high resolution ESI-MS will be used to provide a definitive answer as to whether the ruthenium oligonucleotide products contain the metal in the $+($ II) or $+($ III) oxidation state.

\section{Reactions involving $\left[\mathrm{Pd}(\mathrm{en}) \mathrm{Cl}_{2}\right]$}

Figure 7 shows the negative ion ESI mass spectra of solutions prepared by reacting the oligonucleotide 5'GGCTAGCC-3' with 1, 2 and 4 equivalents of $\left[\mathrm{Pd}(\mathrm{en}) \mathrm{Cl}_{2}\right]$. The two most intense ions in the spectrum of the $1: 1$ reaction mixture [Figure 7(a)] were those at $\mathrm{m} / \mathrm{z} 601.5$ and 801.9 corresponding to $[\text { oligo }-4 \mathrm{H}]^{4-}$ and $[\text { oligo }-3 \mathrm{H}]^{3-}$, respectively. Also present was an ion of high relative intensity at $m / z \quad 856.7$ arising from $[\mathrm{Pd}(\mathrm{en})(\text { oligo })-5 \mathrm{H}]^{3-}$, and a less intense ion at $\mathrm{m} / \mathrm{z} \quad 911.4$ attributable to 
$\left[\{\mathrm{Pd}(\mathrm{en})\}_{2}(\text { oligo })-7 \mathrm{H}\right]^{3-}$. Ions arising from unreacted oligonucleotide were not present in the spectra of the $2: 1$ and $4: 1$ reaction mixtures. In the case of the $2: 1$ reaction mixture [Figure 7(b)], the most abundant ion was at $\mathrm{m} / \mathrm{z}$ 911.6 attributable to $\left[\{\mathrm{Pd}(\mathrm{en})\}_{2}(\text { oligo })-7 \mathrm{H}\right]^{3-}$, where two $\mathrm{Pd}(\mathrm{en})$ moieties are coordinated to the oligonucleotide. This ion was also evident in the spectrum of the $4: 1$ palladium : oligonucleotide reaction mixture. However, the most intense ion in this spectrum [Figure 7(c)] was that at $\mathrm{m} / \mathrm{z}$ 966.9. This ion has been tentatively assigned to $\left[\{\mathrm{Pd}(\text { en })\}_{3}(\mathrm{oligo})-9 \mathrm{H}\right]^{3-}$, for which the calculated $\mathrm{m} / \mathrm{z}$ is 967.1. Further evidence for this assignment is provided by the fact that the peak is extremely broad as would be expected if three palladiums were present, since this element has five isotopes with natural abundances $\geq 10 \%$. Figure 7(c) also contains an intense ion at $\mathrm{m} / \mathrm{z} 1021.8$ consistent with the species $\left[\{\operatorname{Pd}(e n)\}_{4}(\text { oligo })-11 \mathrm{H}\right]^{3-}$, where four $\operatorname{Pd}(\mathrm{en})$ moieties are bound to the oligonucleotide.

Palladium forms four-coordinate square planar coordination complexes in an analogous fashion to the isoelectronic platinum(II). Both metals show a preference for complexes with "soft" ligands, however, palladium(II) complexes are significantly more reactive than analogous platinum(II) complexes. ${ }^{48}\left[\mathrm{Pd}(\mathrm{en}) \mathrm{Cl}_{2}\right]$ contains two labile chloride leaving groups that would be expected to readily undergo hydrolysis leading to highly reactive species such as $\left[\mathrm{Pd}(\mathrm{en})\left(\mathrm{H}_{2} \mathrm{O}\right) \mathrm{Cl}\right]^{+}$and $\left[\mathrm{Pd}(\mathrm{en})\left(\mathrm{H}_{2} \mathrm{O}\right)_{2}\right]^{2+}$. The most favourable binding sites for palladium(II) on the oligonucleotide 5'-GGCTAGCC-3' are the N-7 atoms of the guanines and the adenine base. It is likely that at low Pd : oligonucleotide ratios a single palladium forms an intrastrand crosslink with the two adjacent guanines, leading to the ion at $m / z$ 856.7. On addition of excess metal ion, coordination of a second palladium to the adjacent adenine and guanine bases occurs. Tandem mass spectrometry will be used in future work to provide corroborative evidence for these assignments.

It is more difficult to propose binding sites on the oligonucleotide for the third and fourth $\mathrm{Pd}(\mathrm{en})$ groups present in the ions responsible for peaks at $\mathrm{m} / \mathrm{z}, 966.9$ and 1021.8. The strong thermodynamic driving force towards formation of intrastrand crosslinks with adjacent purines, combined with steric hindrance that would result from coordination of two Pd(en) units to the GG and AG sequences, are factors that suggest coordination of more than two $\mathrm{Pd}(\mathrm{en})$ moieties is unlikely. Furthermore, coordination to either a cytosine or thymine moiety would not be expected to be favourable. This leaves the possibility that the ions at $\mathrm{m} / \mathrm{z}, 966.9$ and 1021.8 arise from gas-phase chemistry in the ion source, and do not reflect the presence of these ions in solution. In order to examine this possibility each reaction mixture was separated by HPLC, and the ESI mass spectra of the individual fractions obtained.

Three fractions were collected from the $1: 1$ reaction mixture and analysed by ESI-MS. The spectrum of the first fraction was dominated by ions from the unreacted oligonucleotide. In the second fraction, lower intensity ions corre-

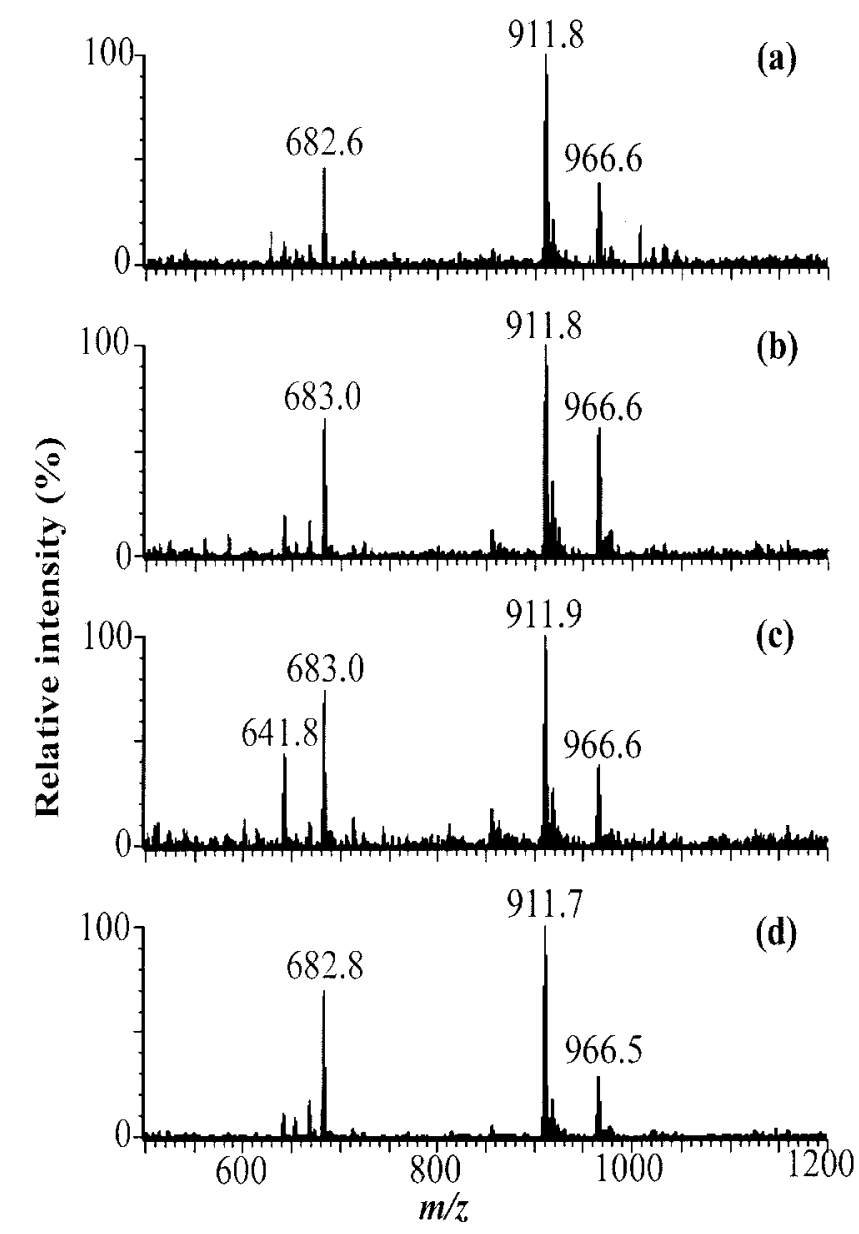

Figure 8. Negative ion ESI mass spectra of four fractions ( $a, b, c$ and d) obtained after HPLC purification of a $4: 1$ $\left[\mathrm{Pd}(\mathrm{en}) \mathrm{Cl}_{2}\right]$ : 5'-GGCTAGCC-3' reaction mixture.

sponding to unreacted oligonucleotide were present, while the most intense ions were those at $\mathrm{m} / \mathrm{z}, 642.4$ and 856.9 arising from a complex in which one $\mathrm{Pd}(\mathrm{en})$ group was bound to the oligonucleotide. The intensities of both of these ions were lower in the spectrum of the third fraction, which instead contained an intense ion at $\mathrm{m} / \mathrm{z}$ 911.6, attributable to the complex containing two $\mathrm{Pd}(\mathrm{en})$ groups bound to the oligonucleotide. No ions of significant intensity from unreacted oligonucleotide were present in the spectra of any fraction obtained after purification of the $2: 1$ reaction mixture by HPLC. Instead the spectrum of each fraction contained ions corresponding to one or two $\mathrm{Pd}(\mathrm{en})$ units bound to the oligonucleotide, with ions arising from $\left[\{\operatorname{Pd}(\text { en })\}_{2}(\right.$ oligo $\left.)\right]$ becoming more abundant in the later HPLC fractions. The 4:1 reaction mixture was separated into four fractions, none of which gave spectra (Figure 8) showing significant ions from unreacted oligonucleotide. There were also only low intensity ions arising from the complex containing a single $\mathrm{Pd}(\mathrm{en})$ group bound to the oligonucleotide, whereas relatively intense ions attributable to a complex containing two such coordinated units were evident in each spectrum $(\mathrm{m} / \mathrm{z}$ 911.7). The spectrum of each 
fraction also contained only medium intensity ions at $\mathrm{m} / \mathrm{z}$ 966.6 attributable to the complex containing three $\operatorname{Pd}($ en) groups bound to the oligonucleotide, while no significant ions attributable to a complex containing four such groups were detected. These latter observations are surprising considering the intensity of ions arising from metal oligonucleotide complexes containing three or four $\operatorname{Pd}(\mathrm{en})$ moieties in the spectrum of the reaction mixture itself [c.f. Figure 7(c)]. This lends support to the view that these complexes arise predominantly from gas-phase associations between the oligonucleotide and the excess palladium present in the reaction mixture.

\section{Conclusion}

Reactions between metal ions and nucleic acids play many important roles in biological systems and in the mechanisms of action of chemotherapeutic agents. While a great deal is known about the interactions of platinum(II) complexes with DNA, comparatively little is known about the reactions of other transition metals and the structures of the resulting complexes. We have demonstrated that ESI-MS can be used to monitor reactions of simple ruthenium and palladium complexes with oligonucleotides. By providing information concerning the stoichiometry of the binding of metal ions and their associated ligands on reaction with DNA, mass spectrometry has the potential to be a rapid, sensitive and complementary technique to NMR spectroscopy for the routine characterisation of such systems.

Cis- and trans-[ $\left.\mathrm{RuCl}_{2}(\mathrm{DMSO})_{4}\right]$ formed adducts with DNA that underwent significant fragmentation during ionisation/transport in the ESI source, resulting in a number of ions in which chloride and/or DMSO ligands were lost from expected reaction products. As a result, the formation of the expected products from reactions of cis- and trans$\left[\mathrm{RuCl}_{2}(\mathrm{DMSO})_{4}\right]$ with 5'-GGCTAGCC-3' could not be verified. It was possible to determine that only one ruthenium was bound to the oligonucleotide in the major product of reactions with both isomers. Reactions of oligonucleotides with either palladium or ruthenium complexes bearing chelating ligands formed products which were apparently more stable since less in-source fragmentation was observed resulting in much simpler spectra. As expected, the ruthenium(III) complex mer-[Ru(terpy) $\left.\mathrm{Cl}_{3}\right]$ proved to be far less reactive towards oligonucleotides than the ruthenium(II) complex cis-[Ru(bipy) $)_{2} \mathrm{Cl}_{2}$ ], except when the reducing agent ascorbate was present in the reaction mixture. We are currently exploring the question of whether ruthenium in products of reactions between mer-[Ru(terpy) $\left.\mathrm{Cl}_{3}\right]$ and oligonucleotides are in the $2+$ or $3+$ oxidation state by use of a higher resolution mass analyser.

$\left[\mathrm{Pd}(\mathrm{en}) \mathrm{Cl}_{2}\right]$ proved to be the most reactive of the complexes examined, with strong evidence for the formation of significant amounts of a complex in solution containing two Pd(en) moieties bound to 5'-GGCTAGCC-3'. The spectra of reaction mixtures containing a $4: 1$ ratio of palladium: oligonucleotide gave a strong indication that significant amounts of metal oligonucleotide adducts containing three or four bound $\operatorname{Pd}(\mathrm{en})$ groups were present. HPLC separation of these reaction mixtures and subsequent ESI-MS analysis suggested that these species arise from gasphase chemistry, and do not exist to a significant extent in solution. This provides a salient warning that ESI mass spectra must be carefully interpreted in the light of all available evidence concerning the binding modes of the metal complex of interest.

In many of the reactions examined, it is highly likely that the metal ion forms 1,2-intrastrand crosslinks with either adjacent purine bases or 1,3-intrastrand crosslinks between purines separated by a third base. Determining the number of bases that are coordinated to a particular metal ion, and indeed the identity of those bases, are fundamentally important questions that need to be answered in order to gain a full understanding of how metal anticancer agents work. We are currently pursuing answers to these questions with the metal complexes examined using a combination of tandem mass spectrometry and other techniques.

\section{Acknowledgments}

MMS would like to acknowledge the support she received from Professor Maccoll at various stages in her career. The Australian Research Council supported this work. We thank Mr Rajesh Gupta for purification of some of the oligonucleotides. Grants from the Australian Research Council, Ramaciotti Foundation and the University of Wollongong enabling the purchase of the electrospray mass spectrometer are also gratefully acknowledged.

\section{References}

1. J.A. Cowan, Inorganic Biochemistry, An Introduction, 2nd Edn. Wiley-VCH, New York, USA (1997).

2. W.I. Sundquist and A. Klug, Nature 342, 825 (1989).

3. J.K. Barton, in Bioinorganic Chemistry, Ed by. I. Bertini, H.B. Gray, S.J. Lippard and J.S. Valentine. University Science Books, Mill Valley CA, USA, p. 455 (1994).

4. P. Pil and S.J. Lippard, in Encyclopedia of Cancer, Ed by J.R. Bertino. Academic Press, San Diego, USA, p. 392 (1997).

5. H.M. Pinto and J.H. Schornagel (Eds), Platinum and Other Metal Coordination Compounds in Cancer Chemotherapy 2. Plenum, New York, USA (1996).

6. B. Lippert, Ed, Cisplatin-Chemistry and Biochemistry of a Leading Anticancer Drug. Wiley-VCH, Weinheim, Germany (1999).

7. A. Eastman, Biochemistry 25, 3912 (1986). 
8. A.M.J. Fichtinger-Schepman, J.L. van der Veer, J.H.J. den Hartog, P.H.M. Lohman and J. Reedijk, Biochemistry 24, 707 (1985).

9. L.R. Kelland, in Uses of Inorganic Chemistry in Medicine, Ed by N.P. Farrell. Royal Society of Chemistry, Cambridge, UK, p. 107 (1999).

10. W. Kaim and B. Schwerderski, Bioinorganic Chemistry: Inorganic Elements in the Chemistry of Life: An Introduction and Guide. John Wiley \& Sons, Chichester, UK, Ch. 19 (1994).

11. N. Farrell and S. Spinelli, in Uses of Inorganic Chemistry in Medicine, Ed by N.P. Farrell. Royal Society of Chemistry, Cambridge, UK, p. 124 (1999).

12. G. Natile and M. Coluccia, in Metallopharmaceuticals I. DNA Interactions, Ed by M.J. Clarke and P.J. Sadler. Springer-Verlag, Berlin, Germany, p. 73 (1999).

13. G. Sava, E. Alessio, A. Bergamo and G. Mestroni, in Metallopharmaceuticals I. DNA Interactions, Ed by M.J. Clarke and P.J. Sadler. Springer-Verlag, Berlin, Germany, p. 143 (1999).

14. T. Preper, K. Borsky and B.K. Keppler, in Metallopharmaceuticals I. DNA Interactions, Ed by M.J. Clarke and P.J. Sadler. Springer-Verlag, Berlin, p. 171 (1999).

15. J.R. Stults and J.C. Masters, Rapid Commun. Mass Spectrom. 5, 354 (1991).

16. N. Potier, A. Van Dorssalaer, Y. Cordier, O. Roch and R. Bischoff, Nucleic Acids Res. 22, 3895 (1994).

17. D.M. Reddy, R.A. Rogers, M.C. Torres and C.R. Iden, Anal. Biochem. 220, 200 (1994).

18. J.A. Kowalak, S.C. Pomerantz, P.F. Crain and J.A. McCloskey, Nucleic Acids Res. 21, 4577 (1993).

19. X. Cheng, D.G. Camps, Q. Wu, R. Bakhtiar, D.L. Springer, B.J. Morris, J.E. Bruce, G.A. Anderson, C.G. Edmonds and R.D. Smith, Nucleic Acids Res. 24, 2183 (1996).

20. G. Wickham, P. Iannitti, J. Boschenok and M.M. Sheil, FEBS Lett. 360, 231 (1995).

21. G. Wickham, P. Iannitti, J. Boschenok and M.M. Sheil, J. Mass Spectrom. S197 (1995).

22. P. Iannitti, M.M. Sheil and G. Wickham, J. Amer. Chem. Soc. 119, 1490 (1997).

23. G. Lowe, J.A. McCloskey, J. Ni and T. Vilaivan, Bioorg. Med. Chem. 4, 1007 (1996).

24. P. Iannitti-Tito, A. Weimann, G. Wickham and M.M. Sheil, manuscript submitted for publication (The Analyst).

25. D.C. Gale, D.R. Goodlett, K.J. Light-Wahl and R.D. Smith, J. Amer. Chem. Soc. 116, 6027 (1994).

26. D.C. Gale and R.D. Smith, J. Am. Soc. Mass Spectrom. 6, 1154 (1995).

27. A. Triolo, F.M. Arcamone, A. Raffaelli and P. Salvadori, J. Mass Spectrom. 32, 1186 (1997).

28. A. Kapur, J.L. Beck and M.M. Sheil, Rapid Commun. Mass Spectrom. 13, 2489 (1999).
29. I. Rombeck and B. Lippert, Inorg. Chim. Acta 273, 31 (1998).

30. J.M. Davey, K.L. Moerman, S.F. Ralph, R. Kanitz and M.M. Sheil, Inorg. Chim. Acta 281, 10 (1998).

31. P.A. Adcock, R.F. Keene, R.S. Smythe and M.R. Snow, Inorg. Chem. 23, 2336 (1984).

32. I.P. Evans, A. Spencer and G. Wilkinson, J. Chem. Soc. Dalton Trans. 204 (1973).

33. S.J. Jaswal, S.J. Rettig and B.R. James, Can. J. Chem. 68, 1808 (1990).

34. J. Sambrook, E.F. Fritsch and T. Maniatis, in Molecular Cloning, a Laboratory Manual, 2nd Edn. Cold Spring Harbour Laboratory Press, New York, USA (1989).

35. E. Alessio, G. Mestroni, G. Nardin, W.M. Attia, M. Calligaris, G. Sava and S. Zorzet, Inorg. Chem. 27, 4099 (1988).

36. M. Coluccia, G. Sava, F. Aoseto, A. Nassi, A. Boccarelli, D. Giordano, E. Alessio and G. Mestroni, Eur. J. Cancer 29A, 1873 (1993).

37. S. Cauci, E. Alessio, G. Mestroni and G. Quadrifoglio, Inorg. Chim. Acta 137, 19 (1987).

38. P.M. van Vliet, J.G. Haasnoot and J. Reedijk, Inorg. Chem. 33, 1934 (1994).

39. O. Novakova, J. Kasparkova, O. Vrana, P.M. van Vliet, J. Reedijk and V. Brabec, Biochemistry 34, 12369 (1995).

40. B.K. Keppler and W. Rupp, J. Cancer Res. Clin. Oncol. 111, 166 (1986).

41. G. Sava, S. Pacor, G. Mestroni and E. Alessio, Clin. Exp. Metastasis 10, 273 (1992).

42. P.M. van Vliet, S.M.S. Toekimin, J.G. Haasnoot, J. Reedijk, O. Novakova, O. Vrana and V. Brabec, Inorg. Chim. Acta 231, 57 (1995).

43. R. Vilaplana, M.A. Romero, M. Quiros, J.M. Salas and F. Gonzalez-Vilchez, Metal Based Drugs 2, 211 (1995).

44. M.J. Clarke, in Metal Ions in Biological Systems, Ed by H. Sigel. Marcel Dekker, New York, USA, p. 231 (1980).

45. M.J. Clarke, in Metal Complexes in Cancer Chemotherapy, Ed by B.K. Keppler. VCH, Weinheim, Germany, p. 129 (1993).

46. G. Mestroni, G. Zassinovich, E. Alessio and A. Bontempi, Inorg. Chim. Acta 137, 63 (1987).

47. M.J. Clarke, Prog. Clin. Biochem. Med. 10, 25 (1989).

48. R.G. Wilkins, Kinetics and Mechanism of Reactions of Transition Metal Complexes, 2nd Edn. VCH, Weinheim, Germany (1991).

Received: 14 December 1999

Revised: 22 February 2000

Accepted: 27 February 2000

Web Publication: 26 May 2000 